July 2006

\title{
Holding Leaders Accountable in the International Criminal Court (ICC) for Gender Crimes Committed in Darfur
}

Kelly Dawn Askin

Follow this and additional works at: https://digitalcommons.usf.edu/gsp

\section{Recommended Citation}

Askin, Kelly Dawn (2006) "Holding Leaders Accountable in the International Criminal Court (ICC) for Gender Crimes Committed in Darfur," Genocide Studies and Prevention: An International Journal: Vol. 1: Iss. 1: Article 6.

Available at: https://digitalcommons.usf.edu/gsp/vol1/iss1/6

This Articles is brought to you for free and open access by the Open Access Journals at Digital Commons @ University of South Florida. It has been accepted for inclusion in Genocide Studies and Prevention: An International Journal by an authorized editor of Digital Commons @ University of South Florida. For more information, please contact digitalcommons@usf.edu. 


\title{
Holding Leaders Accountable in the International Criminal Court (ICC) for Gender Crimes Committed in Darfur
}

\author{
Kelly Dawn Askin
}

\begin{abstract}
This article discusses how rape and other forms of sexual violence have been prominent features of the ongoing attacks (from 2003 to the present) committed by government of Sudan (GoS) troops and the Janjaweed (Arab militia) in Darfur, Sudan. It first provides a historical overview of wartime rape in law and society, then discusses some of the many reports (including the UN's Commission of Inquiry on Darfur) that have documented the perpetration of rape and other forms of sexual violence in Darfur by GoS troops and Janjaweed. Following a discussion of specific cases of rape and other sexual crimes committed in Darfur, the author discusses how such crimes can be and have been prosecuted as war crimes, crimes against humanity, and genocide. Among the other issues discussed in the essay are the concepts of individual and superior responsibility, as they relate to prosecuting those responsible for sexual violence, and the critical need to hold leaders accountable for sex crimes.
\end{abstract}

Sex crimes have a devastating impact far beyond the individuals physically violated by the assaults-these assaults destroy lives, families, communities, and associated groups. Not only must those who survive the violence suffer an attack committed against the most intimate, sacred parts of their bodies but they are also, especially if the crime committed against them is reported to authorities or becomes known, forced to endure the additional psychological, familial, social, cultural, legal, and religious implications of these attacks, both on themselves and on others. No other form of violence has such a broad-reaching adverse impact on both victims and associated groups. Vile acts such as amputating limbs, beheading, and torture instill horror, but these crimes do not routinely cast stigmas or affect marriageability.

To intensify fear and humiliation, rapes in many violent conflicts are committed publicly and by more than one assailant. Women's reproductive capacity-including their potential to bear children for the victim or the victimizer group-is one of numerous reasons women and girls are singled out for sexual assault. Discriminatory laws, customs, and practices regulating female sexual activity and sexual purity impose additional harms, instead of conferring protection. More detrimental consequences of sexual violence, such as HIV/AIDS, other contagious sexually transmitted diseases or infections, and damage to the reproductive system, are also common. Furthermore, the shame and stigma wrongly imputed to victims of sex crimes and to their families; the historical practice of criminal justice systems (police, prosecutors, judges, legislators) that marginalize or ignore rape crimes or, worse,

Kelly Dawn Askin, "Holding Leaders Accountable in the International Criminal Court (ICC) for Gender Crimes Committed in Darfur." Genocide Studies and Prevention 1, 1 (July 2006): 13-28. (C) 2006 from Genocide in Darfur: Investigation into Atrocities in the Sudan edited by Samuel Totten and Eric Markusen. Reproduced by permission of Routledge/Taylor \& Francis Group, LLC. 
revictimize the victims; the sheer terror that threats of such crimes evoke; the severe medical and reproductive repercussions; and the simple fact that, for countless cowardly combatants, unlawfully attacking an unarmed woman or girl and raping her is more "attractive" than legitimately attacking an armed soldier/militia memberthese are some of the reasons that sexual violence has become such an effective and potent instrument of war and vehicle of terror and destruction.

Rape and other forms of sexual violence have been prominent features of attacks committed by government of Sudan (GoS) forces and their Janjaweed (JJW) proxy against non-Arabs in all three states of Darfur. In fact, it is difficult to find a comprehensive report on the most serious crimes committed in Darfur that does not include sex crimes. Murder, rape, pillage, forced displacement, and razing of villages are part and parcel of ground attacks. If a village attack involves either GoS forces or their Janjaweed puppets and collaborators on the ground, rape virtually always forms part of the attack. Even in instances when the primary purpose of a particular attack is not to kill or displace civilians but instead, for example, to steal their cattle, rape still routinely occurs. And when the primary purpose of an attack is to inflict maximum harm on the civilians and drive survivors into the desert and out of the territory, sex crimes are particularly rampant and vicious. ${ }^{1}$

A multitude of reports on crimes committed in Darfur has been published over the past two years, and, as in other armed conflicts around the world, these reports confirm that sexual violence is committed both strategically and opportunistically in Darfur. $^{2}$ Opportunistic rapes are committed because the atmosphere of war and the violence, lawlessness, chaos, and hatred it produces create the opportunity. Random rapes cause as much fear and trauma as orchestrated crimes, sometimes more, because of their unpredictability. Once it becomes clear that superiors do not disapprove of sexual violence, the opportunistic rapes typically become more public, more frequent, and more vicious, growing indistinguishable from and becoming part of the organized rapes committed, at least in part, to inflict widespread terror and harm on the targeted group.

Even if it cannot be proved that rape was officially encouraged or initially intended, when the crimes become well known and superiors fail to disapprove of them, or acquiesce and tolerate the abuse, this signals tacit approval. And, in fact, the whole world was repeatedly informed of the rapes in Darfur. Undoubtedly, political and military leaders in Sudan knew of them, and their silence demonstrated official tolerance and even encouragement. By the time the government expressed its purported outrage over the rapes, they had been raging unabated for some two years; hundreds of thousands had been killed, millions were displaced, and Darfur was in shambles as a result of the scorched-earth policy of the GoS. The conditions of life intentionally inflicted upon black Darfuris are so dire that women and girls have been forced to knowingly risk rape by venturing outside internally displaced persons (IDP) camps for the food and firewood they need to survive inside the camps.

\section{The Historical Treatment of Wartime Rape in Law and Society}

Since the beginning of recorded wartime history, rape has been a common characteristic of armed conflict. From Viking invasions to the Crusades to World Wars I and II, and the hundreds of intra- and international armed conflicts in between, there is a litany of reports of rape and other sexual atrocities committed during the course of the conflict. The literature is so replete with depictions of rape during war that it is exceptional to read in detail about one (war) without reading about the other (rape). 
Yet, until relatively recently, most reports depicted sexual assault as an inevitable consequence, a regrettable byproduct, or simply a common feature of war, not as a serious crime, much less a means of attack that could in fact significantly and dramatically affect the war.

Beginning in the late Middle Ages, the customs of war gradually began to treat rape as a war crime and not as the legitimate right of a victor-part of the so-called spoils of war-as had been largely accepted until about the fifteenth century. For centuries, rape was considered primarily a crime committed against a man's property. By the end of the nineteenth century, wartime rape was widely criminalized but seldom punished. Even by the mid-twentieth century, rape was regarded principally as a crime against honor or dignity, not a crime of violence. ${ }^{3}$ And there is little indication that it was then considered as bad as-or worse than-death.

In contemporary law, sexual violence is a crime under both customary and codified laws. More recently, wartime rape was explicitly forbidden by the Fourth Geneva Convention (1949) and the Additional Protocols to the Geneva Conventions (1977). ${ }^{4}$ Furthermore, the laws of war strictly mandate that combatants direct attacks solely against military objectives, including other combatants; they can never lawfully direct attacks against civilians or civilian objects. ${ }^{5}$ When militaries respect the laws of war, promote notions of honor, and even, perhaps, punish those of their own soldiers who commit sex crimes, rape still occurs (as it does in law-abiding societies during peacetime.) Even when rape is strictly forbidden by superiors who enforce the laws and take measures to prevent or punish the crime, though it takes place less frequently, and certainly less conspicuously, it remains a persistent occurrence (as do other war crimes). However, when the targeting of civilians and the abuse of women is not expressly forbidden by military and political leaders, and its perpetration is either explicitly or implicitly encouraged, simply ignored, or, in some circumstances, even ordered, the regularity and brutality of the crime increase exponentially. This is the situation in most contemporary armed conflicts, including that in Darfur. Thus, while the sexual violence committed in Darfur is horrific, sexual depravity is not unusual during conflict situations, and sexual atrocities are not unique to Darfur. The universal recognition that rape is epidemic in armed conflict, and has been from time immemorial, puts all on notice, including leaders, about the frequent commission of sexual violence.

\section{Sexual Violence in Darfur}

Many reports have documented atrocities in Darfur, and more than a dozen reports documenting these crimes have focused exclusively on rape and other forms of sexual violence, indicating its perceived gravity, its pervasiveness, and its need for redress. ${ }^{6}$ International and local human rights organizations, UN bodies and agencies, and government agencies, monitors, and reporters have been among those expressing alarm over the persistent episodes of sexual violence committed during attacks on villages, while victims are in flight, and inside and outside IDP and refugee camps. Nonetheless, because of significant underreporting of the crime (due largely to discriminatory treatment of victims by law and society), the number of rapes undoubtedly greatly exceeds even the high numbers already known. Male rapes and other forms of sexual violence (especially mutilation) are increasingly reported and also occur with far greater frequency than statistics indicate.

Sex crimes are almost always accompanied by other forms of violence or abuse, such as beatings, forced nudity, enslavement, inhumane conditions, or destruction 
of homes, families, communities, and livelihoods. Many victims are killed after being raped, but some are left alive, sometimes because many perpetrators consider rape worse than death. ${ }^{7}$ Pregnancy and damage to reproductive health are also regular features of rapes; self-induced abortions to terminate the pregnancies are not uncommon.

In 2004, the United Nations appointed five independent commissioners to investigate and report on the most serious crimes perpetrated in Darfur. The Commission of Inquiry (COI) into crimes committed in Darfur released its report in January 2005, concluding that atrocity crimes had been committed in all three states of Darfur by both Sudanese government forces and Janjaweed militia. In summarizing its conclusion on the crimes committed on a widespread and systematic basis throughout Darfur, the report states as follows:

Based on a thorough analysis of the information gathered in the course of its investigations, the Commission established that the Government of the Sudan and the Janjaweed are responsible for serious violations of international human rights and humanitarian law amounting to crimes under international law. In particular, the Commission found that Government forces and militias conducted indiscriminate attacks, including killing of civilians, torture, enforced disappearances, destruction of villages, rape and other forms of sexual violence, pillaging and forced displacement, throughout Darfur. These acts were conducted on a widespread and systematic basis, and therefore may amount to crimes against humanity. ${ }^{8}$

The COI Report outlines the most common patterns of rape crimes, which had been previously documented and were then confirmed by the commissioners' own investigations:

First, deliberate aggressions against women and girls, including gang rapes, occurred during the attacks on the villages. Second, women and girls were abducted, held in confinement for several days and repeatedly raped during that time. Third, rape and other forms of sexual violence continued during flight and further displacement, including when women left towns and IDP sites to collect wood or water. In certain areas, rapes also occurred inside towns. Some women and girls became pregnant as a result of rape. ${ }^{9}$

As other reports similarly conclude, rape, gang rape, sexual slavery, and pregnancy as a result of rape were recurring themes in attacks throughout hundreds of villages in North, West, and South Darfur.

The most extensive documentation of crimes committed in Darfur, including sex crimes, was collected by the Coalition for International Justice and US State Department's Atrocities Documentation Project in July and August 2004, during which more than 1,100 interviews were conducted in refugee camps in Chad and in several other unofficial makeshift camps just inside the Chad-Sudan border. ${ }^{10}$ Testimony of sexual violence obtained by the Atrocities Documentation Teams (ADT) includes the following (names of villages are typically spelled phonetically; numbers in parentheses are ADT interview numbers): ${ }^{11}$

- "In Western Darfur (near Beida) in June 2003, a Masaleit man saw the Janjaweed cut out the stomachs of pregnant women. If the fetus was male, the JJW [Janjaweed] hit the fetus against a tree; if female, the fetus was left in the dirt. The witness stated his sister was [also] raped." (41)

- "In Western Darfur (near Foro Borunga) in June 2003, a Fur man said his wife was raped by seven GoS soldiers, and thirteen other women were also raped during the attack. He saw horsemen take a baby from a woman's back, tear off 
its clothes and slice its stomach; another woman's baby daughter was smashed against a tree and killed. He witnessed approximately twenty male and seven female babies being killed." (6)

- "A Fur woman fled an attack on her village in Darfur (near Bendesi) in August 2003. She witnessed a twelve-year-old girl being gang raped by five men; the girl died soon after the attack. The witness also heard of many children being abducted as slaves or cow-herders." (4)

- "During an attack in West Darfur (near Gokor) in November 2003, a Masaleit woman was among forty women captured and gang raped by seven soldiers during an aerial and ground attack. Some males were also sexually assaulted." (336)

- “A Masaleit woman in West Darfur (near Senena) in December 2003 said twenty girls were captured by GoS and gang-raped (vaginally and anally) for three days. Three girls had nails put in their vaginas (one of whom died), two other girls had their vaginas sewn up, and five became pregnant from the rapes. All were unmarried." (491)

- "In West Darfur (near Genena) in December 2003, a Masaleit woman stated that she and six other women were taken to a GoS base (Dongeta) where they were held for three days and repeatedly gang raped (vaginally and anally, sometimes with sticks) while tied naked and spread eagle. The witness saw the bodies of three naked elderly women with foreign objects thrust in their vaginas. She also said another woman told her she had been tied to a tree and forced to watch her daughter being raped." (497)

- "A Masaleit woman in West Darfur (near El Geneina) in February 2004 saw GoS soldiers catch sixteen women with babies. They broke the baby boys' necks in front of the mothers and beat mothers with their own babies like whips until the babies died." (482)

- "In Northern Darfur (near Karnoi) in January 2004, a pregnant Zaghawan woman and four girls (aged 12,13, 15, 16) were abducted and raped by five to six soldiers each night, until their release five days later." (161)

- "A Zaghawa woman in North Darfur (near Karnoi) had her village attacked in March 2004 and she and eight other women were abducted and raped. After a month, an officer with two stars on his shoulder made the soldiers let the women go." (170)

The ADT interviewers also recorded testimony of epithets or slurs directed at the victims during the course of the sexual assaults. Rape often lasts for long periods, and the perpetrators tend to communicate some of the reasons behind the attacks. Some of the rape testimony collected by the ADT that includes racial or gendered comments is reproduced here:

- "During an aerial and ground attack on a village in North Darfur (near Karnoi) in June 2003, a female Zaghawa survivor reported that she was told 'we want to kill the men and take the women to be our wives." (542)

- "During an attack in Western Darfur (near Masteri) in November 2003, a Masaleit woman was raped by ten soldiers who said that the government 'sent them to kill and rape and clean their land."' (287)

- "During a ground attack in Western Darfur (near Seleya) in November 2003, a Eregnan man reported hearing 'we will kill all men and rape women. We want 
to change the color. Every woman will deliver red. Arabs (will be) the husbands of those women." (533)

- "During a village attack in Western Darfur (near Kruink) in November 2003, a male Masaleit witness reported seeing twelve women raped and mutilated (breasts and vaginas cut) by GoS and JJW, and being told 'you have no country here, you must leave and go to Chad." (325)

- "A Masaleit woman in West Darfur (near El Geneina) in December 2003 saw Arabs take eight male babies by their feet and slam them into the ground until they died; the JJW told women being raped: 'We rape you to make a free baby, not a slave like you!"” (489)

- "A Fur male reported that in December 2003, a few months before his village in West Darfur (near El Geneina) was attacked, Janjaweed raped his daughter and two other girls (ages 14, 15, 16) and said 'We will take your women and make them ours. We will change the race." (575)

- "During an attack on her village in Western Darfur (near Misterei) in January 2004, a Masaleit woman reported that she was one of sixteen women caught and raped during an aerial/ground attack. She was raped by four soldiers. Three other rapes she witnessed included having breasts slashed; two girls died from the gang rapes. The attackers told her 'if you like this stay in Sudan, if you don't, go to Chad."' (259)

- "A Zaghawa woman in North Darfur (near Kotum) in March 2004 stated that sixteen girls from her village were abducted and gang raped. A perpetrator said 'From now and for twenty years we will kill all the blacks and all of the Zaghawa tribe."' (803)

- "A Masaleit woman in South Darfur (near Garsila) had her village attacked in June 2004 by GoS and JJW. Despite being four months pregnant, she fled, but was caught running by five men. They beat her with a whip, causing her to lose her baby. The attackers said: 'Black prostitute, whore-you are dirty blacks." (1056)

The incidents described above represent only a fraction of the reports of various forms of sexual violence inflicted on the black indigenous population in Darfur, but they demonstrate the consistency of the reasons behind the attacks, the regularity with which rape crimes occur, and the calculated use of rape as an instrument to terrorize and destroy the targeted group. The gendered nature of many attackstargeting fetuses or babies because of their sex and targeting some women because of their reproductive capacity or pregnancy—should not be minimized. Time and again interviewees told of black Darfuris being raped, raped in gangs or with foreign objects, or having breasts, vaginas, or penises mutilated; pregnant women having their wombs sliced open or women having their pregnancies forcibly aborted by beatings or other abusive treatment; babies, particularly male babies, being murdered; women made pregnant by the rapes; men and women forced into nudity; and women and girls being abducted and sexually enslaved. Males are often targeted in armed conflicts because they are viewed as the fighters or potential fighters; females are targeted because they are viewed as the repositories of culture and the (re)producers of generations, or simply as the gender intended to serve and service men. The form and nature of the violence often reflects these attitudes.

In the most progressive societies, impediments to reporting, investigating, and prosecuting rape still abound. In conservative and religious societies like Sudan, 
the obstacles multiply. In particular, as mentioned above, the misplaced shame and stigma of rape crimes and revictimization by criminal justice systems cause this crime to be underreported. When extremist laws or practices, such as the Islamic laws operating in Darfur, require women or girls to prove a rape by the testimony of four male witnesses and to be subjected to an insensitively or crudely conducted government medical exam, there is little incentive, and many disincentives, to reporting the crime. This is particularly true because the survivor may be charged with zena (adultery or having sex outside of a marital relationship) if she cannot prove the rape, especially if she is pregnant. Such a charge may result in public whippings and imprisonment, perhaps even a death sentence. At a minimum, it can result in the survivor's being cast out of the community and precluded from marrying. In addition, the dysfunctional and discriminatory court system in Darfur-not to mention the fact that the courts are controlled by the government, which is considered responsible for the atrocities-further reduces reporting of sex crimes. ${ }^{12}$

\section{Rape as Genocide and a Crime against Humanity}

Since the mid-1990s, many articles and books have focused on how rape and other forms of sexual violence can be and have been prosecuted as war crimes, crimes against humanity, and genocide. ${ }^{13}$ Crimes include rape, enslavement, sexual slavery, torture, persecution, mutilation, enforced sterilization, forced pregnancy, forced abortion, forced nudity, sexual humiliation, forced marriage, cruel treatment, and inhumane acts, some of which are explicitly listed in the International Criminal Court (ICC) Statute, while others are implicitly covered under the statute's "or any other form of sexual violence of comparable gravity" language. ${ }^{14}$ Judgments in the Yugoslav Tribunal (the International Criminal Tribunal for the former Yugoslavia, ICTY) and the Rwanda Tribunal (the International Criminal Tribunal for Rwanda, ICTR) have also convicted individuals of rape as crimes against humanity and instruments of genocide. ${ }^{15}$ Because, as noted above, there is already a plethora of information available on how gender-related crimes can be successfully prosecuted, these issues will be given only cursory treatment here.

The ICC can prosecute gender-related crimes under articles 6 (genocide), 7 (crimes against humanity), and 8 (war crimes) of the ICC Statute. The gender crimes specifically enumerated in the statute are rape, enforced prostitution, sexual slavery, forced pregnancy, enforced sterilization, and other forms of sexual violence of comparable gravity. Additionally, gender persecution and trafficking of women and children are also explicitly referred to in the statute. ${ }^{16}$

Under the UN Convention on the Prevention and Punishment of the Crime of Genocide (UNCG) and the ICC Statute, "genocide" means any of the acts listed in article II, sub-paragraphs (a)-(e), committed with intent to destroy, in whole or in part, a national, ethnic, racial, or religious group as such. The five prohibited acts are as follows:

(a) Killing members of the group;

(b) Causing serious bodily or mental harm to members of the group;

(c) Deliberately inflicting on the group conditions of life calculated to bring about its physical destruction in whole or in part;

(d) Imposing measures intended to prevent births within the group; or

(e) Forcibly transferring children of the group to another group. 
"Killing members of a group," prohibited in (a), is undoubtedly the most widely recognized means of committing genocide, although all five sub-articles are equally prohibited. The other sub-articles do not necessarily involve death, or even outright violence, as a means of destroying a group. Rape as an instrument of genocide most often invokes sub-articles (b), intending to destroy a protected group by "causing serious bodily or mental harm to members of that group," and (d), "imposing measures intended to prevent births within a group." ${ }^{17}$ As noted above, rape, along with torture and enslavement, including sexual torture and sexual slavery, regularly takes longer to commit than other crimes, and the extended time and close proximity of the perpotrator and the victim often prompt statements by the perpetrator(s) that can be useful in discerning genocidal intent. The Akayesu Judgment of the Rwanda Tribunal is the seminal decision recognizing rape as an instrument of genocide.

The ICTY and ICTR have also convicted persons for rape as a crime against humanity when the crimes formed part of a widespread or systematic attack directed against a civilian population. It is the attack that must be either widespread or systematic, not the rapes, although rape itself is frequently both widespread and systematic. The phrase "systematic rape" does not mean that each rape is meticulously organized and planned; it refers, among other things, to a plan or policy to sexually abuse women, which is often carried out by implicitly or explicitly encouraging or granting free rein to commit the crime.

There is every indication that the official policy of the GoS and Janjaweed forces is to wage, jointly or separately, concentrated and strategic attacks against black Darfuris by a variety of means, including killing, raping, pillaging, burning, and displacement. Various forms of sexual violence have consistently formed part of these attacks. As emphasized by the COI report, "The findings of the Commission confirm that rape and sexual abuse were perpetrated during attacks by Janjaweed and soldiers. This included the joint attacks by Government soldiers and Janjaweed attacks." 18 BBC News reported the following regarding the attack of one village: "More than 100 women have been raped in a single attack carried out by Arab militias in Darfur in Western Sudan... Another 150 women ... have been abducted."19 Rape crimes have been documented in dozens of villages throughout Darfur and committed in similar patterns, indicating that rape itself is both widespread and systematic.

The information available on crimes in Darfur suggests that the ICC can prosecute rape as a crime against humanity and an instrument of genocide and that other forms of sexual violence, particularly forced pregnancy, sexual mutilation, and sexual slavery, are also common prosecutable forms of attack and destruction in Darfur.

\section{Individual and Superior Responsibility}

The ICC can prosecute both physical perpetrators and others responsible for sexual violence, including civil and military leaders and others who ordered, instigated, aided, abetted, or otherwise facilitated the crimes (individual responsibility), or who knew or had reason to know about crimes committed by subordinates under their control but failed to prevent, halt, or punish the crimes (superior responsibility). In most situations, the persons most responsible for orchestrating war and the atrocities committed therein are not the physical perpetrators or even those physically present at the crime sites, unless they are military/militia leaders. More specifically, in the ICC Statute, individual criminal responsibility grants the court jurisdiction over persons 
who commit a crime, individually or jointly; who order, solicit, or induce a crime; or who aid, abet, assist, or otherwise facilitate a crime. Participating in a common criminal purpose may also incur individual criminal responsibility. ${ }^{20}$ Command and superior responsibility is invoked (1) for military leaders and other superiors who knew or should have known of crimes, or consciously disregarded information about them; and (2) where the crimes were committed by subordinates under their effective responsibility/authority/command and control, and they failed to take all necessary and reasonable measures within their power to prevent or repress the crimes or to report the crimes to the relevant competent authorities for investigation and prosecution. $^{21}$

In the jurisprudence of the World War II trials, as well as the ICTY and the ICTR, and as incorporated in the ICC Statute, ${ }^{22}$ crimes may be punished under the joint criminal enterprise (JCE) theory of responsibility (also known as the common purpose doctrine). Essentially, a JCE is considered a form of commission, a form of individual criminal responsibility. A JCE is composed of a plurality of persons participating in some way (through assistance or other contribution) in a common plan/design/purpose that amounts to or involves a crime within the jurisdiction of the court. The common plan can be agreed upon in advance, can materialize extemporaneously, and can be inferred from the facts. ${ }^{23}$

The ICTY has identified three distinct, but often overlapping, forms of JCE: JCE I is the basic form, in which all co-defendants share the same criminal intent or goal; they knowingly participate in some way and intend the result. JCE II is the systemic form. It is a subset of JCE I and has primarily been applied to concentration camps or situations where there is an orchestrated campaign of persecution or oppression. In JCE II, there is an organized system of ill treatment, and defendants have awareness of the nature of the system and an intent to further that system. There is some form of participation in the system, but their participation does not have to be significant. JCE III is the extended form, whereby responsibility for crimes committed beyond the common plan can be incurred. This happens when a perpetrator-not necessarily the defendant-commits a crime outside the common purpose, but the act is a natural or foreseeable consequence of the criminal endeavor. Here, a defendant willingly takes a risk that additional predictable crimes will be committed. The various forms may, and often do, overlap or occur parallel to each other. ${ }^{24}$

In a culture of mass atrocity, it may sometimes be difficult to determine which crimes were part of the agreed-upon enterprise and which were outside the scope of the intended crimes but nonetheless foreseeable. But in most situations of mass violence and oppression, rape and other common forms of sexual violence will not be mere foreseeable consequences; rather, they should be considered integral parts of the destruction, of the physical and mental violence intentionally inflicted on the targeted group. The fear and terror inflicted by sexual violence rivals, and sometimes exceeds, that of murder; it is a crime calculated to inflict maximum harm on the targeted group. Treating sex crimes as simply foreseeable (JCE III) but killing, beating, torturing, and burning as intended (JCE I) or part of a system of ill treatment (JCE II) would distort the historical record and ignore the gravity and potency of the crimes. Thus, rape crimes should be prosecuted under JCE I and II, with JCE III rape prosecutions restricted to situations in which the joint criminal plan was very specific (e.g., summary execution of all boys over thirteen years of age in a village) and the rapes that occur are truly not planned but are nonetheless foreseeable. ${ }^{25}$ 
In Darfur, the evidence suggests that GoS political and military leaders participated in a joint criminal enterprise with their Janjaweed collaborators, whom the GoS armed, supplied, and directed for at least the first two years. Initially, many attacks were joint GoS and Janjaweed attacks, until virtually all black African villages had been attacked; after that, the GoS appears to have largely left it to the Janjaweed and regular bandits to complete the destruction on the ground. From February 2003 to March 2005, in particular, a common mode of attack in Darfur was for a GoS plane or helicopter to bypass Arab villages and carry out an attack (or surveillance) on black villages, in concert with or followed by ground attacks by government forces or government-supported Janjaweed militia. During the course of these attacks, civilian huts were destroyed; men, women, and children killed; women and girls raped; animals and other property stolen; child cattle herders and others abducted; and survivors forced into the inhospitable desert.

Aerial and ground attacks also commonly targeted life sources, such as water and food supplies, shelter, arable land, crops, livestock, and medical supplies. ${ }^{26}$ In the context of Darfur, with temperatures soaring to $130^{\circ} \mathrm{F}$ in the harsh desert environment during the day but dropping dramatically some nights, such destruction was especially effective and quite naturally resulted in death and illness. Starvation, dehydration, exposure, infection, and disease were intended results of the intentional destruction of life sources and forced displacement.

The ad hoc tribunals have refined but not significantly developed the concept of command/superior responsibility beyond that promulgated by the post-World War II trials; most indictees in the Yugoslav (ICTY) and Rwanda (ICTR) Tribunals have been found guilty of individual responsibility. Indeed, the courts have found not only that many leaders regularly failed in their duty to prevent or punish crimes committed by subordinates but, more egregiously, incurred individual responsibility for facilitating the commission of the crimes. As might be expected, leaders who orchestrate, authorize, condone, encourage, or otherwise assist criminal activity do not then tend to endeavor to stop the crimes they have orchestrated or to punish those who committed the crimes they themselves have authorized. Therefore, the ICTY and ICTR have tended to either convict on individual responsibility and dismiss the superior responsibility charges or find that the superior responsibility crimes were subsumed within the crimes incurring individual responsibility. Thus, the notion seems to be that if one orders a crime, one should not also be held responsible for failing to punish the subordinate who carried out one's orders.

Ignoring crimes committed by subordinates initially might fall under superior responsibility, failure to act. But when the silence continues, a potent message is sent to subordinates that superiors do not disapprove of their crimes, and this signals tacit approval, invoking individual responsibility. Additionally, JCE, being a form of commission, is a form of individual responsibility, not superior responsibility. Still, when there is insufficient evidence available to prove that a leader participated in a JCE or facilitated the commission of a crime, holding him (or her) responsible for his duty to prevent or punish crimes committed by the de facto or de jure subordinates under his command and control remains a viable option.

The ICC Prosecutor, Luis Moreno-Ocampo, has consistently stated that his office intends to focus on leaders bearing the greatest responsibility for the most serious crimes. For Sudan, then, the ICC will likely indict less than a dozen civil and military leaders (including those of the Janjaweed/militia) for war crimes, crimes against humanity, and possibly genocide in Darfur. There is little dispute that war crimes and 
crimes against humanity, including sex crimes, have been committed. Many genocide experts have concluded that genocide has also been committed in Darfur. ${ }^{27}$ The COI Report unconvincingly reached a different conclusion, leading the government of Sudan to imply that the commission had exonerated it of all serious criminal activity. The US government has called the crimes in Darfur a genocide and, despite its hostility to the ICC, did not veto a Security Council resolution referring the situation in Darfur to the ICC. ${ }^{28}$

\section{Holding Leaders Accountable for Sex Crimes}

As noted above, the ICC has indicated that it intends to focus principally on investigating those holding the highest level of responsibility for justiciable crimes. Leaders have a duty to protect the civilian population and provide justice to those who have been victims of crimes. In Darfur, government leaders have not only failed in this duty but are also implicated in committing or otherwise facilitating the atrocities. In Kvocka, the ICTY Trial Chamber emphasized that special measures need to be taken to ensure that women placed in vulnerable positions during armed conflict are protected from sexual violence. It further noted that once they have reports or knowledge of such crimes, persons in positions of authority are placed on notice; to prevent being held accountable, they must take extra measures to prevent sex crimes. ${ }^{29}$ Even if one took the dubious view that consistent reports of rape crimes in conflicts throughout the world over the past thousand years, not to mention the explosion of rape reports filed during wars over the last decade, did not put leaders on notice that sexual assaults are a common means of destroying a community or harming a targeted group, the recurring monthly reports of rape crimes in Darfur certainly did put the political and military leaders in Sudan on notice that rape was a frequent occurrence there. Reports by the United Nations, of which Sudan is a member, also highlight the prevalence of rape and raise it as a grave concern.

A wide range of UN experts has repeatedly noted that rape crimes flourish in Darfur with the full knowledge of the government. For example, Louise Arbour, the UN's high commissioner for human rights and the former chief prosecutor of the ICTY and ICTR, as well as a former member of the Supreme Court of Canada, has stressed that "there is a credible base of evidence that there is a severe, severe, serious amount of sexual violence that is not being properly addressed." ${ }^{30}$ On 21 June 2005, Jan Egeland, the UN undersecretary for humanitarian affairs, reported that "in Darfur, rape is systematically used as a weapon of warfare." ${ }^{31}$ In March 2004, Mukesh Kapila, the UN coordinator for Sudan, discussing the mass rape committed in Darfur, emphasized that "it is more than just a conflict. It is an organized attempt to do away with a group of people."32 Sima Samar, UN special rapporteur for human rights in Sudan, has stated that "gender-based violence continues unfortunately with impunity" and that the government's excuses were unacceptable. ${ }^{33}$ And Juan Mendez, UN special advisor to the secretary-general on the prevention of genocide, emphasized that even by September 2005, "the rape of women remained too prevalent."34

It is relatively straightforward to hold persons criminally responsible for sex crimes when they commit them physically, directly order the crimes (and there is documentation or other evidence), or are physically present at crime sites and either encourage or otherwise aid and abet the crimes. As noted above, it is also largely accepted that the most culpable government and military leaders do not have to be physically present at crime sites to be held accountable for the policies they have dictated in directing a widespread or systematic attack against a targeted civilian 
group. Nonetheless, when attacks on village after village involve murder, torture, rape, pillage, and forced displacement, in prosecutions, all but the sex crimes will typically be attributed to the leaders as part of their official policy.

While in theory it should not be particularly complicated to hold political/civilian or military leaders criminally responsible, either as individuals or as superiors, for sexual violence when the crimes are widespread or systematic, not to mention notorious, in practice there has been enormous reluctance to hold leaders and non-physical perpetrators accountable for sex crimes, as opposed to other crimes. In general, the attitude seems to be that leaders need not be physically present at crime sites to be held responsible for the carnage that ensues during the course of carrying out a plan or policy to harm the targeted group, whereas sex crimes are regularly treated by investigators, prosecutors, and judges as different, private, or special crimes, outside the scope of any intended attack. The notion-held by many investigators, prosecutors, trial attorneys, and judges-appears to be that leaders should not be held accountable for sex crimes unless there is incontrovertible proof that they ordered the crimes or that they knew about them and personally intended their commission. This attitude is not only legally and factually inaccurate, it is morally untenable, provides a flawed, sexist historical record of the events, and denies justice to half the population. Failing to hold leaders accountable for sex crimes when they occur regularly and consistently over weeks and months, let alone years, suggests that the crimes are not considered serious or are deemed personal/private issues. It also ignores consistent and credible reports that wartime rapes are used strategically as weapons of war or instruments of terror.

That said, the ICTY has recognized that leaders can be held accountable for sex crimes when they neither were present nor ordered the crimes. For example, in the Plavsic case before the ICTY, Biljana Plavsic, a former leader of the Bosnian Serb entity, pled guilty to one count of persecution as a crime against humanity in exchange for dropping the other seven charges, including the genocide counts. To accept a guilty plea, the chamber had to be satisfied that the guilty plea was informed, voluntary, and unequivocal and that there was a sufficient factual basis that the crimes were committed and that the person pleading guilty participated in them. Plavsic's guilty plea on the charge of persecution as a crime against humanity, accepted by the tribunal, included acknowledging responsibility for rape crimes. ${ }^{35}$ The persecution count accused Plavsic of participating in a joint criminal enterprise to plan, instigate, order, and aid or abet the persecution of non-Serbs in Bosnia-Herzegovina. The means of persecution included killing, raping, torturing, forcibly displacing, and committing other inhumane acts against civilians and destroying civilian property. Accepting the guilty plea and convicting Plavsic of persecution as a crime against humanity, the chamber noted that she was neither as influential nor as powerful as many other leaders, and played a lesser role in facilitating the crimes. Nonetheless, she incurred responsibility for rape and other crimes by acquiescing in them. As Plavsic herself stated, "although I was repeatedly informed of allegations of cruel and inhuman conduct against non-Serbs, I refused to accept them or even to investigate." ${ }^{36}$ She thus bore individual responsibility for the crimes, being a leader who knowingly participated in a joint criminal endeavor to persecute non-Serbs. She may not have specifically intended the rapes, but nonetheless she had knowledge of them and made no effort to indicate disapproval, to complain, or to initiate preventive measures, thus incurring individual responsibility for the crimes. ${ }^{37}$ 
To be sure, the orchestraters of mass atrocity in Darfur know what is happening on the ground and receive full and detailed reports of events. The political, military, and militia leaders have no doubt that when they order an attack, the ensuing violence will take many diverse forms, including rape. In the extraordinary event that they were so naïve that they did not know initially, they certainly knew after reports were issued, and still the leaders have continued urging or ignoring unlawful attacks on civilians with full knowledge that rape-and other crimes-would form part of the attacks.

The government of Sudan has not made a secret of its intent to refuse to cooperate with the ICC, including denying visas to ICC investigators and prosecutors seeking to enter the country. Thus there will be some difficulty in investigating crimes within Darfur itself, at least until Sudan is forced or induced to cooperate with the court. Nevertheless, refugees who are victims of and witnesses to crimes in Darfur are in dozens of countries around the world-more than 200,000 in Chad alone-and many would undoubtedly be willing to give evidence to the ICC. States parties to the ICC100 countries, as of November 2005-are required by the ICC Statute to cooperate with the court, and many of these countries have valuable intelligence information on evidence of crimes and the most culpable parties. The UN Security Council, the African Union, the European Union, UN bodies and agencies, and non-governmental organizations can also play a positive role in assisting the court. The obstacles confronting the ICC are many, but with perseverance, integrity, and creativity, the challenges can be overcome and the people of Darfur can receive some measure of justice for the atrocities committed against them.

\section{Notes}

1. See, e.g., Human Rights Watch, "Sexual Violence and Its Consequences among Displaced Persons in Darfur and Chad" (HRW briefing paper, 12 April 2005); Médecins sans Frontières, "The Crushing Burden of Rape: Sexual Violence in Darfur" (MSF briefing paper, 8 March 2005); Report of the International Commission of Inquiry on Darfur to the United Nations Secretary-General (25 January 2005), http://www.un.org/News/dh/sudan/ com_inq_darfur.pdf (accessed 19 April 2006) [COI Report]; Tara Gingerich and Jennifer Leaning, The Use of Rape as a Weapon of War in the Conflict in Darfur, Sudan (Boston: Physicians for Human Rights, 2004); Human Rights Watch, "Empty Promises? Continuing Abuses in Darfur, Sudan" (HRW briefing paper, 11 August 2004); Amnesty International, "Darfur: Rape as a Weapon of War: Sexual Violence and Its Consequences" (AI document AFR 54/076/2004, 19 July 2004).

2. See Nicholas D. Kristof, "Sudan's Department of Gang Rape," New York Times, 22 November 2005; Jonah Fisher, "A Culture of Impunity in Darfur," BBC News, 26 September 2005; Report of the UN Special Advisor on the Prevention of Genocide, Visit to Darfur, Sudan 19-26 September, 2005 (4 October 2005), http://www.protectdarfur.org/ Pages/Download_Docs/Special__Advisor_Report1005.pdf (accessed 19 April 2006).

3. The historical treatment of the laws and customs of war concerning rape, from customary law to codified law, is discussed in detail in Kelly Dawn Askin, War Crimes Against Women: Prosecution in International War Crimes Tribunals (Ardsley, NY: Transnational Publishers, 1997), 18-48.

4. Geneva Convention (IV) Relative to the Protection of Civilian Persons in Time of War, 6 U.S.T. 3516, 75 U.N.T.S. 287 [Fourth Geneva Convention]; Protocol Additional to the Geneva Conventions of 12 August 1949, and Relating to the Protection of Victims of International Armed Conflicts, June 8, 1977, 1125 U.N.T.S. 3, 16 I.L.M. 1331 (entered into force 7 December 1978) [Additional Protocol I]; Protocol Additional to the Geneva Conventions of August 12, 1949, and Relating to the Protection of Victims of 
Non-International Armed Conflicts, June 8, 1977, S. Treaty Doc. No. 100-2, 1125 U.N.T.S. 609 (entered into force 7 December 1978) [Additional Protocol II].

5. Protocol I, arts. 35, 48-60. While the laws of war accept that civilians may be killed or injured during activities directed against military objectives, as "collateral damage," nonetheless civilians cannot be the object of or the target of an attack. Further, many precautions are required to be taken to minimize the risk of civilians being injured during an attack against military objects.

6. See, e.g., Amnesty International, "Sudan: Surviving Rape in Darfur" (AI document AFR 54/ 097/2004, 9 August 2004); Amnesty International, "Rape as a Weapon of War"; Amnesty International, "Sudan: Mass Rape, Abduction and Murder" (AI document AFR 54/125/ 2004, 10 December 2004); Amnesty International, "Sudan: Systematic Rape of Women and Girls" (AI document AFR 54/038/2004, 15 April 2004); Médecins sans Frontières, "The Crushing Burden of Rape"; Human Rights Watch, "Darfur: Women Raped Even after Seeking Refuge," Human Rights News, 12 April 2005, http://hrw.org/english/docs/2005/04/ 11/sudan10467.htm (accessed 19 April 2006); UNICEF, "Darfur Region in Crisis: Girls and Women Terrorized by Widespread Rape in Darfur" (news release, 20 October 2004); Refugees International, "Rape, Islam and Darfur's Women Refugees and War Displaced" (24 August 2004); Mark Fritz, "In Darfur Wood-Gathering Women Walk through a Minefield of Rape" (International Rescue Committee, 19 August 2004); Tracy Hampton, "Agencies Speak Out on Rape in Darfur," Journal of the American Medical Association 294 (2005): 542-44; Nicholas D. Kristof, "A Policy of Rape," New York Times, 5 June 2005; Lydia Polgreen, "Darfur's Babies of Rape are on Trial from Birth," New York Times, 11 February 2005; Robyn Dixon, "In Sudan, Rape's Lasting Hurt," LA Times, 15 September 2004; Emily Wax, "'We Want to Make a Light Baby': Arab Militiamen in Sudan Said to Use Rape as Weapon of Ethnic Cleansing," Washington Post, 30 June 2004; Sam Dealey, "Rape Is a Weapon in Darfur, but Sudan's Government Doesn't Want to Hear about It," Sudan Times, 28 August 2005, TIME/US edition; BBC News, "Mass Rape Atrocity in West Sudan," 19 March 2004; BBC News, "UN Attacks Darfur 'Fear and Rape," 25 September 2004; Somini Sengupta, "Rampage of Rape in Sudan Continues Undeterred," New York Times, 27 October 2004; Sudan Organisation Against Torture, "Darfur: Abduction and Rape in Nyala" (press release, 20 September 2005); Alexis Masciarelli and Ilona Eveleens, "Sudanese Tell of Mass Rape," BBC News, 10 June 2004.

7. For example, Refugees International reports, “As you have raped me, please don't leave me alive... kill me with your gun' begged Almina to her rapist. 'May shame kill you' was the reply of the Janjaweed militiaman who raped her." Refugees International, "Rape, Islam, and Darfur's Women Refugees."

8. COI Report, 3 .

9. Ibid., paras. 334-36.

10. See US Department of State, Documenting Atrocities in Darfur (21 September 2004), http:// www.state.gov/g/drl/rls/36028.htm (accessed 19 April 2006).

11. Unpublished statements collected by the CIJ/USAID Atrocities Documentation Project (on file with author).

12. See, especially, Access to Justice for Victims of Sexual Violence: Report of the United Nations High Commissioner for Human Rights (29 July 2005), 13-26, http://www.ohchr.org/english/press/docs/20050729Darfurreport.pdf (accessed 19 April 2006).

13. Like many other academics, legal experts, and journalists, I have previously written on various ways to prosecute gender crimes; I do not want to repeat them again here. See, e.g., Askin, War Crimes Against Women; Kelly D. Askin, "Sexual Violence in Decisions and Indictments of the Yugoslav and Rwandan Tribunals: Current Status," American Journal of International Law 93 (1999): 97-123; Kelly D. Askin, "Crimes within the Jurisdiction of the International Criminal Court," Criminal Law Forum 10 (1999): 33-59; Kelly D. Askin, "Women and International Humanitarian Law," in Women and International Human Rights Law, vol. 1, ed. Kelly D. Askin and Dorean M. Koenig, 41-87 (Ardsley, NY: Transnational Publishers, 1999); Kelly D. Askin, "The International War Crimes Trial of 
Anto Furundzija: Major Progress Toward Ending the Cycle of Impunity for Rape Crimes," Leiden Journal of International Law 12 (1999): 935-55; Dorean M. Koenig and Kelly D. Askin, "International Criminal Law and the International Criminal Court Statute: Crimes against Women," Women and International Human Rights Law, vol. 2, ed. Kelly D. Askin and Dorean M. Koenig, 3-29 (Ardsley, NY: Transnational Publishers, 2000); Kelly Dawn Askin, "Women's Issues in International Criminal Law: Recent Developments and the Potential Contribution of the ICC," in International Crimes, Peace, and Human Rights: The Role of the International Criminal Court, ed. Dinah Shelton, 47-63 (Ardsley, NY: Transnational Publishers, 2000); Kelly D. Askin, "Comfort Women: Shifting Shame and Stigma from Victims to Victimizers," International Criminal Law Review 1 (2001): 5-32; Martina Vandenberg and Kelly D. Askin, "Chechnya: Another Battleground for the Perpetration of Gender Based Crimes," Human Rights Review 2 (2001): 140-56; Kelly D. Askin, "The Quest for Post-Conflict Gender Justice," Columbia Journal of Transnational Law 41 (2003): 509-21; Kelly D. Askin, "The Kunarac Case of Sexual Slavery: Rape and Enslavement as Crimes Against Humanity," in Annotated Leading Cases of International Criminal Tribunals, vol. 5, ed. Andre Klip and Goran Sluiter, 806-17 (Antwerp:

Intersentia, 2003); Kelly D. Askin, "Prosecuting Wartime Rape and Other Gender Related Crimes under International Law: Extraordinary Advances, Enduring Obstacles," Berkeley Journal of International Law 21 (2003): 288-367; Kelly Dawn Askin, "The International Criminal Tribunal for Rwanda and Its Treatment of Crimes against Women," in International Humanitarian Law: Challenges, vol. 2, ed. John Carey, William V. Dunlap, and R. John Pritchard, 33-88 (Ardsley, NY: Transnational Publishers, 2004); Kelly D. Askin, "Gender Crimes: Jus Cogens Violations and Universal Jurisdiction," in African Perspectives on International Criminal Justice, ed. Evelyn A. Ankumah and Edward K. Kwakwa, 57-66 (Maastricht: Africa Legal Aid, 2005); Kelly Dawn Askin, "Gender Crimes Jurisprudence in the ICTR," Journal of International Criminal Justice 3 (2005): 1007-18; Kelly D. Askin, "The Jurisprudence of International War Crimes Tribunals: Securing Gender Justice for Some Survivors," in Listening to The Silences: Women and War, ed. Helen Durham and Tracey Gurd, 125-54 (Leiden: Martinus Nijhoff, 2005).

14. Rome Statute of the International Criminal Court, 1998 Sess., U.N. Doc. A/CONF.183/9 (1998) (entered into force 1 July 2002) [ICC or Rome Statute], art. 7.

15. See, e.g., Prosecutor v. Akayesu, Judgment, ICTR-96-4-T (2 September 1998) [Akayesu Trial Judgment]; Prosecutor v. Kunarac et al., Judgment, IT-96-23-T \& IT-96-23/1 (22 February 2001) [Kunarac Trial Judgment]; Anne-Marie L.M. de Brouwer, Supranational Criminal Prosecution of Sexual Violence: The ICC and the Practice of the ICTY and the ICTR (Antwerp: Intersentia, 2005).

16. ICC Statute, art. 6, art. 7(1)(g), and art. 8(b)(xxii) and 8(e)(vi). Under the crimes against humanity provisions of the statute, "enslavement" is specifically noted to include "the exercise of such power in the course of trafficking in persons, in particular women and children" (art. 7(2)(c)) and "persecution" explicitly includes gender-based persecution (art. $7(1)(\mathrm{h}))$.

17. See, e.g., Askin, War Crimes against Women.

18. COI Report, para. 338.

19. BBC News, "Mass Rape Atrocity."

20. ICC Statute, art. 25.

21. Ibid., art. 28 (the requirements for military commanders and other superiors are slightly different.)

22. Ibid., art. 25(3)(d).

23. Prosecutor v. Tadic, Judgment, 1T-94-1-A (15 July 1999) [Tadic Appeals Judgment], para. 227.

24. See, e.g, ibid., paras. 195-229; Prosecutor v. Kvocka, Judgment, IT-98-30-T (2 November 2001), paras. 79-86 [Kvocka Trial Judgment]; Prosecutor v. Kvocka, Judgment, IT-98-30-A (28 February 2005), paras. 77-119 [Kvocka Appeals Judgment]; Prosecutor $v$.

Ntakirutimana, Judgment, ICTR-96-10A \& ICTR-96-17A (13 December 2004), paras. 
461-68; Prosecutor v. Milutinovic et al., Decision on Dragoljub Odjanic's Motion Challenging Jurisdiction-Joint Criminal Enterprise, IT-99-37-AR72 (21 May 2003); Prosecutor v. Stakic, Judgment, IT-97-24-T (31 July 2003), paras. 438-42; Prosecutor $v$. Krnojelac, Judgment, IT-97-25-A (17 September 2003), paras. 64-124; Prosecutor $v$. Vasiljevic, Judgment, IT-98-32-A (25 February 2004), paras. 94-111; Prosecutor $v$. Brdjanin, Decision on Interlocutory Appeal, IT-99-36-A (19 March 2004). See also Rwamakuba v. Prosecutor, ICTR-44-AR72.4, Decision on Interlocutory Appeal Regarding Application of Joint Criminal Enterprise to the Crime of Genocide (22 October 2004).

25. See, e.g., Prosecutor v. Krstic, Judgment, IT-98-33-T (2 August 2001), paras. 621-45, in which the summary execution of all men and boys of fighting age in Srebrenica was held to be a joint criminal enterprise (JCE I), but the rape crimes committed during the course of the JCE were deemed foreseeable (JCE III) under the circumstances of mass violence and persecution.

26. See, e.g., Physicians for Human Rights, "Destroyed Livelihoods: A Case Study of Furawiya Village, Darfur" (Preliminary Briefing, 2005), http://www.phrusa.org/research/sudan/pdf/ darfur_briefing.pdf (accessed 19 April 2006).

27. See, for example, some of the reports on Darfur crimes included on the Web sites of Prevent Genocide International, http://www.preventgenocide.org/ (accessed 19 April 2006); Darfur: A Genocide We Can Stop, http://www.darfurgenocide.org/ (accessed 19 April 2006); and Save Darfur, http://www.savedarfur.org (accessed 19 April 2006), as well as Gregory H. Stanton, "Genocide Emergency: Darfur, Sudan" (Genocide Watch, 2 April 2004), http:// www.genocidewatch.org/Never\%20Again.htm (accessed 19 April 2006).

28. U.N. Doc. S.C. Res. 1593, S/RES/1593, 31 March 2005.

29. Kvocka Trial Judgment, para. 318.

30. BBC News, "UN attacks Darfur 'Fear and Rape." The Commission of Inquiry made a similar statement: "On their part, the authorities failed to address the allegations of rape adequately or effectively." COI Report, para. 336.

31. See Claudia Parsons, "Sudan: UN Says Rape Is Systematic Weapon of War in Darfur" (Women Living Under Muslim Laws, 21 September 2005), http://www.wluml.org/english/ newsfulltxt.shtml?cmd\%5B157\%5D=x-157-249107 (accessed 19 April 2006).

32. BBC News, "Mass Rape Atrocity."

33. Quoted in "Sudan Failed to Try Darfur War Crimes-UN Rights Official," Sudan Times, 23 October 2005.

34. Fisher, "Culture of Impunity."

35. See Prosecutor v. Plavsic, Plavsic Sentencing Judgment, IT-00-39 \& IT-00-40/1 (27 February 2003), paras. 27, 29, 34, 120, 126.

36. Ibid., para. 51.

37. Ibid., especially paras. 55, 121. 